\title{
Depositional dynamics in the El'gygytgyn Crater margin: implications for the 3.6 Ma old sediment archive
}

\author{
G. Schwamborn ${ }^{1}$, G. Fedorov ${ }^{2}$, N. Ostanin ${ }^{3}$, L. Schirrmeister ${ }^{1}$, A. Andreev ${ }^{4}$, and the El'gygytgyn Scientific Party \\ ${ }^{1}$ Alfred Wegener Institute for Polar and Marine Research, Telegrafenberg, 14473 Potsdam, Germany \\ ${ }^{2}$ Arctic and Antarctic Research Institute, Bering Street 38, 199397 St. Petersburg, Russia \\ ${ }^{3}$ St. Petersburg State University, Faculty of Geography and Geoecology, 10 line V.O., 33, 199178 St. Petersburg, Russia \\ ${ }^{4}$ Cologne University, Institute for Geology and Mineralogy, Zülpicher Str., 50674 Cologne, Germany
}

Correspondence to: G. Schwamborn (georg.schwamborn@awi.de)

Received: 29 May 2012 - Published in Clim. Past Discuss.: 14 June 2012

Revised: 9 October 2012 - Accepted: 15 October 2012 - Published: 26 November 2012

\begin{abstract}
The combination of permafrost history and dynamics, lake level changes and the tectonical framework is considered to play a crucial role for sediment delivery to El'gygytgyn Crater Lake, NE Russian Arctic. The purpose of this study is to propose a depositional framework based on analyses of the core strata from the lake margin and historical reconstructions from various studies at the site. A sedimentological program has been conducted using frozen core samples from the $141.5 \mathrm{~m}$ long El'gygytgyn 5011-3 permafrost well. The drill site is located in sedimentary permafrost west of the lake that partly fills the El'gygytgyn Crater. The total core sequence is interpreted as strata building up a progradational alluvial fan delta. Four macroscopically distinct sedimentary units are identified. Unit $1(141.5-117.0 \mathrm{~m})$ is comprised of ice-cemented, matrix-supported sandy gravel and intercalated sandy layers. Sandy layers represent sediments which rained out as particles in the deeper part of the water column under highly energetic conditions. Unit 2 (117.0$24.25 \mathrm{~m}$ ) is dominated by ice-cemented, matrix-supported sandy gravel with individual gravel layers. Most of the Unit 2 diamicton is understood to result from alluvial wash and subsequent gravitational sliding of coarse-grained (sandy gravel) material on the basin slope. Unit $3(24.25-8.5 \mathrm{~m})$ has icecemented, matrix-supported sandy gravel that is interrupted by sand beds. These sandy beds are associated with flooding events and represent near-shore sandy shoals. Unit 4 (8.5$0.0 \mathrm{~m}$ ) is ice-cemented, matrix-supported sandy gravel with varying ice content, mostly higher than below. It consists of slope material and creek fill deposits. The uppermost metre is the active layer (i.e. the top layer of soil with seasonal freeze
\end{abstract}

and thaw) into which modern soil organic matter has been incorporated. The nature of the progradational sediment transport taking place from the western and northern crater margins may be related to the complementary occurrence of frequent turbiditic layers in the central lake basin, as is known from the lake sediment record. Slope processes such as gravitational sliding and sheet flooding occur especially during spring melt and promote mass wasting into the basin. Tectonics are inferred to have initiated the fan accumulation in the first place and possibly the off-centre displacement of the crater lake.

\section{Introduction}

El'gygytgyn Crater in the Far East Russian Arctic (Fig. 1) is a Pliocene-aged (3.6 Ma; Layer, 2000) impact crater that offers the unique opportunity to trace terrestrial Arctic palaeoclimate and environmental change back to the time of the impact. Pilot cores have shown that the sedimentary archive is time-continuous, but only recently drill cores penetrating the full basin have become available (Nowaczyk et al., 2002; Melles et al., 2012). It is remarkable that the lake, which partially fills the crater, is positioned off-centre with a flattened area semi-surrounding it; unconsolidated frozen deposits show a distinctly asymmetrical distribution with a broad fringe of loose sediment that is 3 to $4 \mathrm{~km}$ wide in the north and west and only 100 to $200 \mathrm{~m}$ elsewhere around the lake. This raises two questions. Why is this lake offset? What is the nature and history of the unconsolidated permafrost 
margin? Studies of pilot cores from the lake basin show that the lake sediments contain frequent layers of mass movement deposits (Juschus et al., 2007, 2009). The multiple occurrences of debris flows in the basin (Niessen et al., 2007) require environmental conditions that link catchment processes and mass wasting, as represented in the lake records. In order to better understand the catchment-to-lake interaction, a tandem drilling of the crater basin has been achieved; next to a long sediment record of $318 \mathrm{~m}$ penetrating the full lake basin (core 5011-1) (Melles et al., 2012), a $141.5 \mathrm{~m}$ core was extracted from the western permafrost flats (core 5011-3) (Fig. 1). This ensures that the sediment history of the 3.6 Ma old impact crater (Layer, 2000) can be fully explained, including the imprint of catchment processes on the environmental and palaeo climate archive contained in the cores. Permafrost dynamics might govern sediment import into the lake, and understanding the permafrost history of the catchment may thus improve the interpretation of the long lake record. The onshore drilling site was located on the permafrost ramp, where a distinct fan delta enters the lake from the west (Fig. 2). The longitudinal profile close to the crater wall resembles that of an alluvial fan (McEwen et al., 2011), whereas the flat cross-profile in the distal part is more like that of a river delta (Blair and McPherson, 1994). According to field observations, recent material transport is alluvial in nature - mainly taking place during spring melt. Thus, for terminology reasons the name El'gygytgyn alluvial fan delta (EAFD) is favoured.

A detailed sedimentology is the key to understanding the construction of the western permafrost margin of the lake basin. The nature and history of the mid-fan will be elucidated after establishing a description of the material, the grain size, the mineralogy, the organic matter, and the pollen content contained in the core. The purpose of this paper is to document the sedimentary sequence of the western plain and to propose a depositional environment based on analyses of the core strata. This also holds consequences of interpreting the $3.6 \mathrm{Ma}$ old palaeoenvironmental and palaeoclimatic archive of lake core 5011-1.

\section{Geographical setting of El'gygytgyn Crater}

El'gygytgyn Crater is a roughly circular depression, $18 \mathrm{~km}$ in diameter, and partially occupied by a lake that is $12 \mathrm{~km}$ in diameter and $175 \mathrm{~m}$ deep at maximum (Fig. 1). It was created 3.6 Ma ago by a meteor impact (Layer, 2000) and is superimposed on the Okhotsk-Chukchi volcanic belt in the Anadyr hinterland. The volcanic plateau is from the Upper Cretaceous and the strata consist of ignimbrites and tuffs mainly to the east, north, and west, and andesitic rocks located to the south (Belyi, 1998). The hills on the volcanic crater rim rise to between 600 and $930 \mathrm{~m}$ a.s.l. (above sea level), and the lake level is $492 \mathrm{~m}$ a.s.l. Loose Quaternary deposits in a permafrost environment cover the crater plain surrounding the
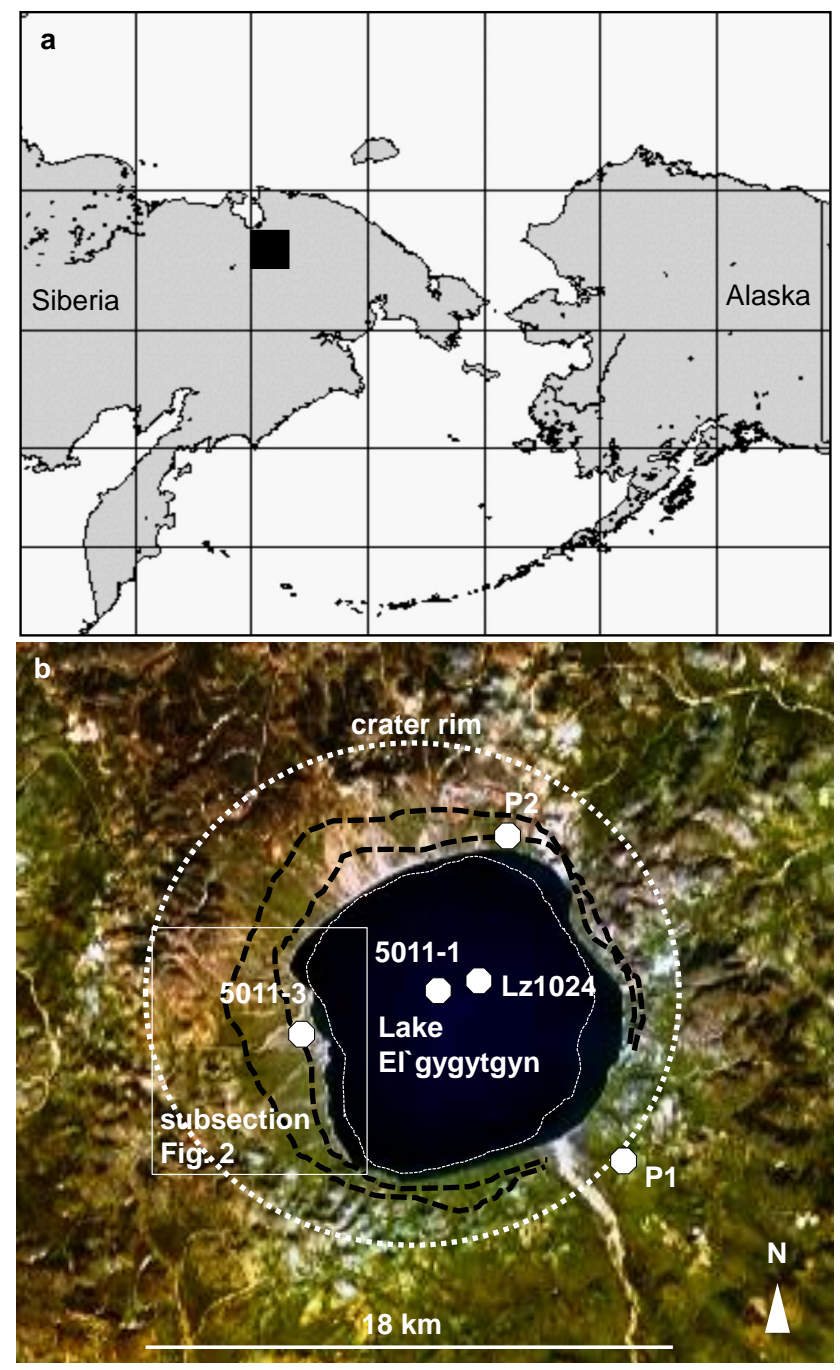

Fig. 1. (a) Geographic position of the El'gygytgyn Crater in NE Russia (black box). (b) A Landsat image showing the crater (dotted line) and drill site 5011-3. 5011-1, Lz1024, P1 and P2 denote for other cores discussed in the text. The lake is east of the crater centre and semi-surrounded by a flat permafrost surface to the west and north. The dashed black lines indicate shorelines of the Middle Pleistocene (outer) and the Late Pleistocene (inner) according to Glushkova and Smirnov (2007). The dashed white line marks the lake level during the LGM according to Juschus et al. (2011).

lake, which is drained by 50 seasonally active inlet streams (Nolan and Brigham-Grette, 2007). In 2003, the active layer was about $0.4 \mathrm{~m}$ deep in peaty silts and reached $0.5-0.8 \mathrm{~m}$ in sand and gravels on the slopes. The site is in the continuous permafrost zone (Yershov, 1998; Schwamborn et al., 2006, 2008) with a MAAT (mean annual air temperature) of $-10^{\circ} \mathrm{C}$ at $3 \mathrm{~m}$ above the ground (Nolan and Brigham-Grette, 2007) and a MAGT (mean annual ground temperature) of $-6.0^{\circ} \mathrm{C}$ at $20 \mathrm{~m}$ depth (Motthagy et al., 2012). Permafrost thickness is estimated to be around $350 \mathrm{~m}$ based on borehole temperature measurements in hole 5011-3 (Mottaghy 
et al., 2012). Air temperature extremes in 2003 ranged from $-40^{\circ} \mathrm{C}$ to $26^{\circ} \mathrm{C}$. Precipitation comprised $70 \mathrm{~mm}$ summer rainfall (June-September) and $110 \mathrm{~mm}$ water equivalent of snow (Nolan and Brigham-Grette, 2007). Humidity between September 2001 and August 2003 ranged from 17\% to $100 \%$ with an average of $80 \%$; the most arid conditions were found in the summer months.

Major storms push lake ice onto the shore to form the uppermost shoreline in the lake. The storms annually change the coastal pebble bar height by 1 to $2 \mathrm{~m}$, to a distance of up to 10 to $20 \mathrm{~m}$ from the lake. Even though prevailing storms come from either a northerly or a southerly direction (Nolan and Brigham-Grette, 2007), these ice-pushed pebble ridges can be seen all around the lake. A lateral series of up to four pebble bars measuring 20 to $200 \mathrm{~m}$ across and up to $4 \mathrm{~m}$ above the present lake level is most conspicuous in the northern part of the basin. The outermost ridge has been dated to Allerød time using AMS ${ }^{14} \mathrm{C}$ ages from a sequence of slope deposits blocked behind the ridge and is linked to a lake level higher at that time than it is today (Schwamborn et al., 2008). Since that time consecutive lake level drops have left behind more pebble bars. The bowl-shaped lake has nearshore shallows up to $1 \mathrm{~km}$ from shore; at water depths of 10 to $12 \mathrm{~m}$ the shallow terrace drops off abruptly to greater depths. This subaqueous terrace was formed during the Last Glacial Maximum (LGM) when the lake had a water level lower than it is today (Juschus et al., 2011). More past lake level reconstructions come from Glushkova and Smirnov (2007), who mapped a Middle Pleistocene-aged shoreline at $540 \mathrm{~m}$ and a Late Pleistocene-aged shoreline at $500 \mathrm{~m}$.

There are no data available that would point to glaciation events in the El'gygytgyn Crater. Glaciation in the Chukotka Peninsula, at least during the late Quaternary, was restricted in extent and characterized by well-defined valley glaciers and coalescing valley glacier complexes from local mountain centres excluding the El'gygytgyn area (Glushkova, 2001). Seismic surveys of the basin fill do not indicate a glacial imprint on the lake sediment column either (Niessen et al., 2007).

Regional tectonic maps from the Chukotka Anadyr mountain belt show a major fault system running through El'gygytgyn Crater (Fig. 3). On three sides, on the west, the east, and the southwest, the crater is intersected by tangential fault lines. The western and eastern faults strike parallel in a NW direction and mark the boundaries of the Malo-Chauns volcano-tectonic Graben structure with the El'gygytgyn Crater located at its southeastern end; the southeastern sector is crossed by a major thrust fault (Belyi and Raikevich, 1994; Stone et al., 2009). It is speculated that the relative uplift of the western mountain chain may have tilted the crater basin and triggered fan and braid plain sedimentation. The lake's shift off-centre towards the east might be another result of this block motion during the local orogenesis. Today's seismicity map indicates that earthquakes with magnitudes up to 4 shake the area (Fujita et al., 2009).
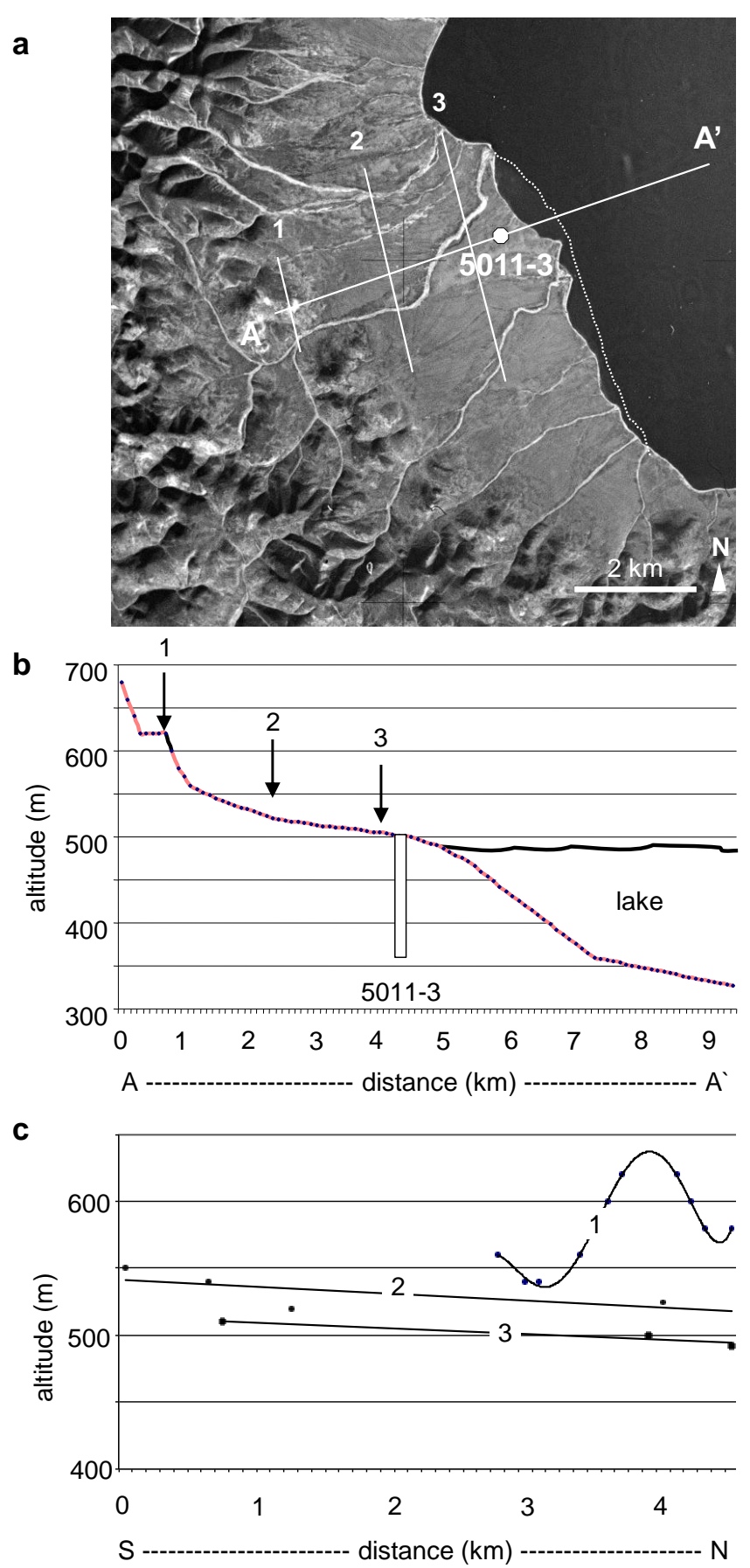

Fig. 2. Topography of the fan surface: (a) enlargement of the subsection in Fig. 1b. Positions of cross profiles 1, 2, and 3 and a radial cross section A-A' running across the fan delta through the 5011-3 permafrost drill site. The faint dotted line indicates the subaquatic fan prolongation. The delta margin might have been partially flooded after a lake level rise (Image source: USGS, CORONA 1216-5, acquisition date: 14 September 1980). (b) Longitudinal profile across the drill site. (c) Cross profiles 1, 2, and 3. 


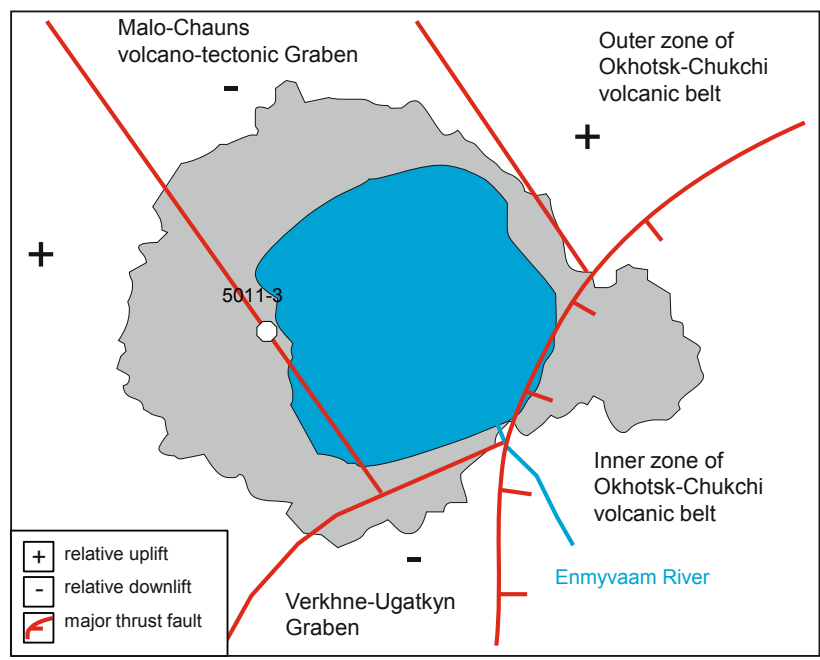

Fig. 3. Tectonic framework around Lake El'gygytgyn according to Belyi and Raikevich (1994) and Stone et al. (2009). The grey area marks the lake's catchment. An uplift of the western block may have caused the lake's offset from the centre and may have initiated fan and braid plain fill to the west and north of the crater.

This may add to surface activation and downslope release of debris.

Generally, fan deltas form as a result of base-level fall of the depositional area relative to the source area. Erosional base-level falls tend to result in temporary thin fans, and tectonic base-level falls tend to result in prolonged accumulation of thick fans (Bull, 1977). There are strong relationships between active orogenic environments and thick accumulations of young fan deposits (Beaty, 1970; Densmore et al., 2007). On the other hand, continued lack of tectonic uplift will change the depositional environment to an erosional environment where pedimentation or flooding events are the main process operating on the landscape (Bull, 1977; Haug et al., 2010). The feeder channel of the EAFD has a terrace architecture, where the two levels of a modern and an ancient riverbed are distinct. The difference in altitude in the mid-fan area is up to one metre with a riverbed width of about $200 \mathrm{~m}$. This suggests that the feeding river had higher water levels in the past and has been eroding this bed to a deeper level in recent times. Alternatively, a base level drop in the course of the Holocene lake level receding or a tectonic uplift in the western crater margin may control the erosional level in the riverbed.

The 5011-3 coring position $\left(76^{\circ} 29.1^{\prime} \mathrm{N}, 171^{\circ} 56.7^{\prime} \mathrm{E}\right)$ is located in the central part of the western permafrost flats (Fig. 2). To the east the closest shore bars are $350 \mathrm{~m}$ away, and to the west the nearest outcropping of volcanic rocks occurs upslope $4 \mathrm{~km}$ away. The area between is covered by talus and slope material. The core position lies $8 \mathrm{~m}$ higher than the lake level on a gently sloping surface $\left(<4^{\circ}\right)$. The coring site is located at the distal end of a fan that is the most distinctive sediment body on the western-to-northern alluvial plain; several fans in a row cover this area. Where the fan spreads out on the plain it measures $3 \mathrm{~km}$ in length and $2 \mathrm{~km}$ in width at its maximum (Fig. 2). The fan margin outline is arcuate where it borders the lake and continues with a subaqueous prolongation on a slope into the lake (Fig. 2). Two small deltaic bodies protrude visibly into the lake and modify the shoreline. Parts of what is today the subaqueous delta have been inundated in the course of a water level rise after the LGM lowstand (see also Fig. 2 in Nolan and Brigham-Grette, 2007). The active feeder channel marks the northern boundary of the fan and might have migrated to its modern position from the south (Fig. 2). The feeder channel of the EAFD and the channel feeding a small delta to the south measure more than $4 \mathrm{~km}$ in length and belong to the longest inlets in the lake catchment. A hummocky tundra environment characterizes the fan surface with a loamy to rubbly substrate. Surface drainage occurs mainly during spring snowmelt. The ground is mostly dry in summer. Creeks are intermittent and ponds do not persist. Conditions may have alternated between seasonally alluvialand debris-flow activity since the onset of EAFD formation; such variability is known from other fan environments (Harvey et al., 2005; Harvey, 2012). Typically, only the most recent processes that have affected fan surfaces are evident.

\section{Material and methods}

Onshore sedimentary permafrost was cored down to $141.5 \mathrm{~m}$ in November 2008 (Melles et al., 2011). Frozen core pieces were recovered with a mining rig (Russian SIF-650M) that was employed by a local drilling company. The rotary drill worked without any fluids and pressured air was used to keep the base of the borehole clean. Core cuttings were caught in a half-open cylinder, which was mounted on top of the drill bit. Individual core runs extracted up to $1.5 \mathrm{~m}$ of core and individual core sections measured up to $0.4 \mathrm{~m}$ long. The core diameter was $0.11 \mathrm{~m}$ and the overall core recovery reached $91 \%$. Cores were labelled and packaged into plastic liners and thermo boxes and kept frozen until they arrived at the laboratory.

\subsection{Log protocol}

The core processing in the field followed a modified protocol that was based on a log protocol provided by the OSG (Operational Support Group) of the ICDP (International Continental Scientific Drilling Program; icdp-online.org). The main components of the core composition were described using codes for the sediment types and the colour, and a note describing sharp orgradational layer contacts. Notes describing plant remains, gas bubbles, or fossils were added whenever necessary. The ground ice fabric was addressed (e.g. ice cement, lens-like, reticulate, massive, or layered), and finally 
digital images were taken to complete the in-field documentation. The log protocol was transferred into a drilling information system that linked the core description with core imagery.

\subsection{Laboratory procedure}

Further laboratory processing included proper cleaning of all sections (i.e. removal of borehole cuttings), and documenting core sections with refined descriptions and digital photography. On average, samples were taken every $0.5 \mathrm{~m}$ or where a sediment change occurred; sections were 15 to $20 \mathrm{~cm}$ long and had a gross weight of about 2 to $3 \mathrm{~kg}$. Frozen samples stored in polyethylene bags were weighed, thawed, and allowed to settle. Thawed ground ice was immediately extracted from the samples using pore water samplers (i.e. rhizones; Seeberg-Elverfeldt et al., 2005). It was analysed for $\mathrm{pH}$ and electrical conductivity (EC) using a WTW Multilab 540. Subsamples were taken for further pore-water analyses. After the remaining sample parts were freeze-dried the gravimetric ice content was determined and is expressed as total water content equivalent in weight percentage (wt \%) of the moist sample. The solid portion of the sample underwent a standard suite of analyses.

Ice cracks were present in the frozen core. This indicates the possible destruction of primary sedimentary structure and sediment grains. Whereas the assessment of mineralogical and organic contents is not sensitive to sediment freezing, the grain size assessment should be treated with caution, since post-depositional grain split-up in the core material due to frost-cracking may have occurred to an unknown extent.

Conventional sieving techniques were carried out in the course of analysing subsamples. The dry gravel portion was separated in a rotating sieve tower (Retsch AS 200 control) into phi-stepped sieves ( $>10 \mathrm{~mm} ;>6.3 \mathrm{~mm} ;>2 \mathrm{~mm}$ ). Selected samples were further dry-sieved for the fractions $>1 \mathrm{~mm}$; >0.5 mm; $>0.25 \mathrm{~mm} ;>0.125 \mathrm{~mm} ;>0.063 \mathrm{~mm}$; $>0.032 \mathrm{~mm}$; and $<0.032 \mathrm{~mm}$ using an ATM SonicSifter with timed mechanical pulsing action. The sieving results were input into the GRADISTAT program developed by S. J. Blott (Blott and Pye, 2001). The program provides sample statistics based on Folk and Ward (1957) and a physical description of the textural group the sample belongs to and the sediment name (such as "fine gravelly coarse sand") following Folk (1954).

For tracing mineral changes, core cuttings of all sections $(n=100)$ were analysed using XRD (X-ray diffractometry). The non-textured pulverized samples were measured on a Philips PW1820 goniometer applying $\mathrm{CoK} \alpha$ radiation $(40 \mathrm{kV}, 40 \mathrm{~mA})$. The semi-quantitative assessment of the main mineral components included the relative quartz, feldspar (plagioclase and orthoclase), and pyroxene amounts. The quartz occurrence is defined using the area below the $4.26 \AA$ peak, whereas plagioclase is measured using the 3.18 and orthoclase the $3.24 \AA$ peak areas. Pyroxene is assessed using an integration of peaks at 2.92 and $3.0 \AA$ (Vogt et al., 2001) with reference to the total peak area of one individual measurement. XRD instrumental settings were according to Petschick et al. (1996), and digital processing of XRD diagrams was performed using "MacDiff" software (Petschick et al., 1996). The following mineralogical quotients were used: kalifeldspar-to-plagioclase, quartzto-feldspar, and pyroxene-to-total peak area (Vogt, 2009; Vogt et al., 2001).

Total organic carbon (TOC) was measured with a Vario EL III element analyser in samples $(5 \mathrm{mg})$ that had been treated with hydrochloric acid $(\mathrm{HCl}, 10 \%)$ at a temperature of $80^{\circ} \mathrm{C}$ to remove carbonate. Samples were heated $\left(1150^{\circ} \mathrm{C}\right)$ and supplied with oxygen during analysis. The TOC content was measured by heat conductivity using helium as a carrier gas. International standard reference materials covering the measured range, as well as double measurements, were used to check for external precision. The following errors were accepted: $\pm 5 \%$ for TOC content $>1 \mathrm{wt} \% ; \pm 10 \%$ for TOC content $<1$ wt $\%$.

A standard hydrofluoric acid (HF) technique was used for pollen preparation from subsamples with grain sizes $<2 \mathrm{~mm}$. At least one sample per core metre was inspected, and (when possible) at least 250 pollen grains were counted in each sample. A total of 210 samples spanning the whole core have been studied for pollen. More specifications related to the pollen analysis are outlined in greater detail in Andreev et al. (2012). Age estimation of pollen zones is based on the correlation with pollen results from relatively well-dated El'gygytgyn lacustrine sediment cores (Lozkhin and Anderson, 2006; Lozkhin et al., 2007) and short permafrost cores from the slopes (Andreev et al., 2012).

\section{Results}

\subsection{The modern environment}

From field observation it was clear that spring meltwater currently transports detritus from the catchment onto the lake ice and into the growing ice-free margin. The detritus consists of material up to the gravel-size range. This sediment transport into the lake's shallow areas is probably responsible for further sediment release to the deep basin promoted by rain and storm events occurring later during the open water season. The shoreline is composed of pebbles forming bars up to $4 \mathrm{~m}$ high that occasionally contain lagoonal ponds in which sandy gravel accumulates. After the spring melt peak, the shoreline barrier system thus acts as a sediment trap; these traps are generally penetrated only by smaller-sized material in the clay and silt range. For a detailed description of the modern sedimentation pattern in the El'gygytgyn Crater Lake the reader is referred to Wennrich et al. (2012). 


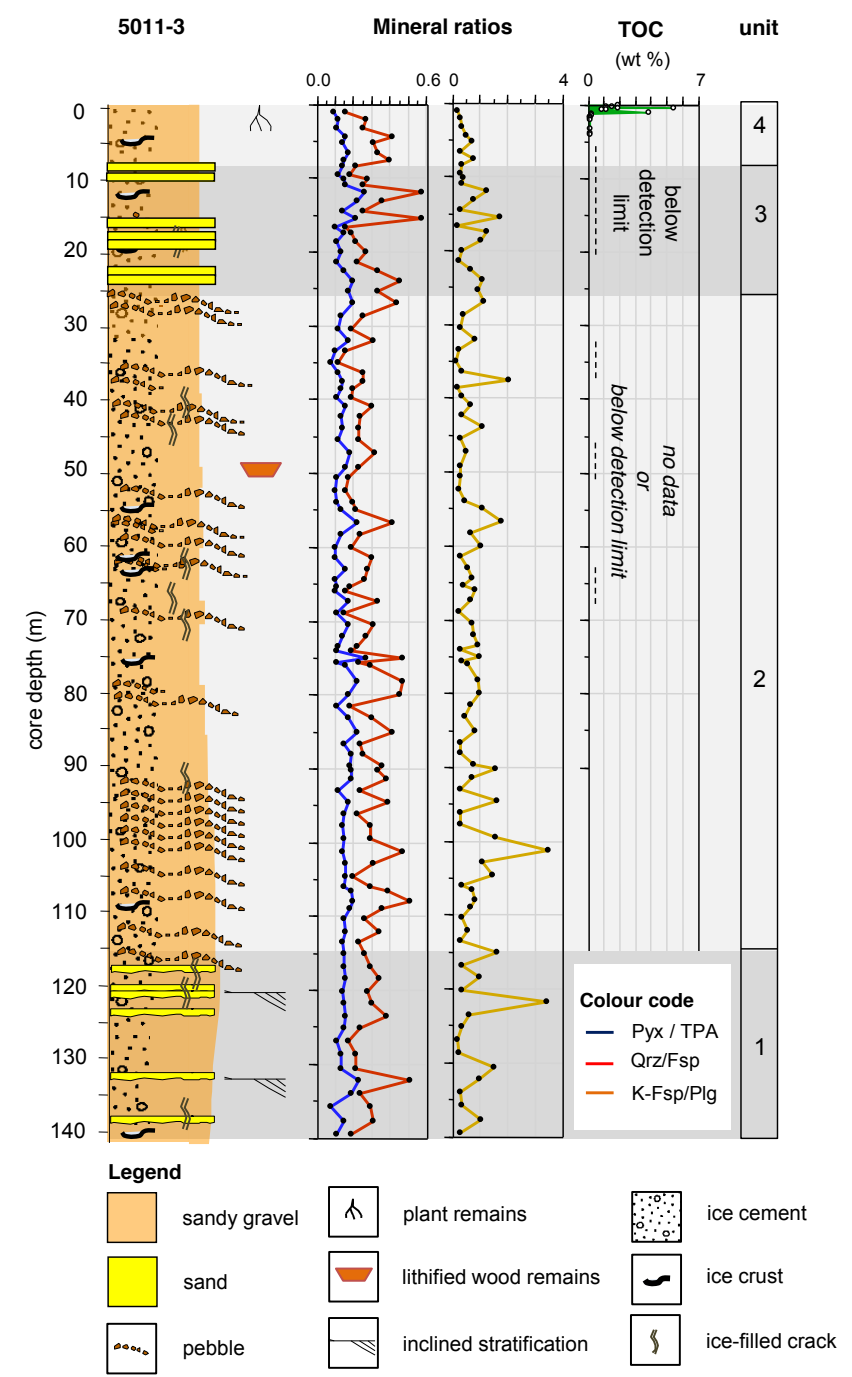

Fig. 4. Lithological $\log$ of core 5011-3 from El'gygytgyn Crater showing the material composition and the subdivision into core units based on macroscopic features. Abbreviations: Qrz=quartz, Fsp=feldspar, K-Fsp = Kali-feldspar, $\mathrm{Plg}=$ Plagioclase, Pyx $=$ Pyroxene, TPA $=$ total peak area.

\subsection{Lithostratigraphy and granulometry}

The cored material can be subdivided into four broad sedimentary units based on macroscopic description. These sedimentary units have distinct properties, as described from the bottom to the top (Figs. 4 and 5).

Unit $1(141.5-117.0 \mathrm{~m})$ is composed of matrix-supported sandy gravel. The mostly red, orange-yellow and brown, partly greenish gravel clasts measure up to $7 \mathrm{~cm}$ in length; they are of volcanic origin with porphyric and ignimbritic textures. Commonly they have a subround to subangular shape. The modal composition shows that medium gravel $(>10 \mathrm{~mm})$ is the most pronounced portion, followed by a distinct mode in the fine pebble fraction and

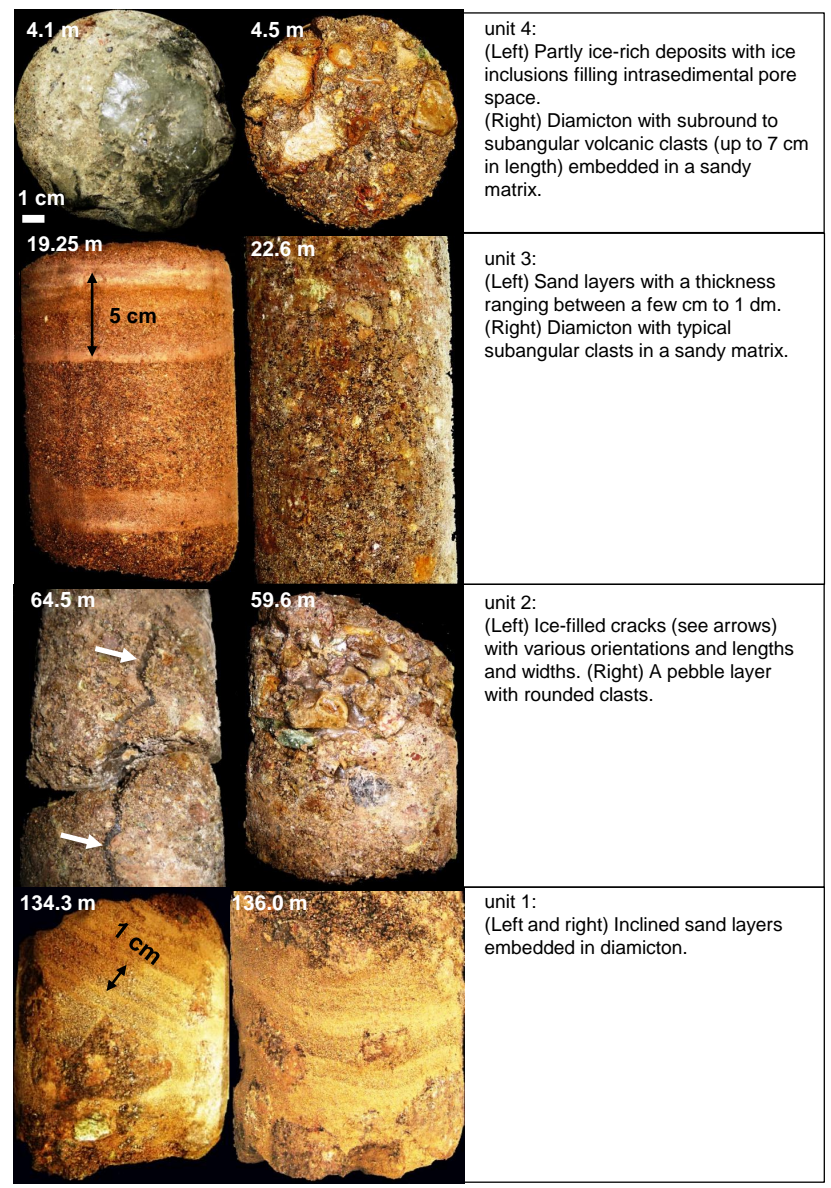

Fig. 5. Photographic examples of sediment structures and ice features in units 1 to 4 . The core diameter is $11 \mathrm{~cm}$.

a minor portion in the coarse to medium sand fraction $(>500 \mu \mathrm{m} ;>250 \mu \mathrm{m})$ (Fig. 6). The gravel-to-sand boundary $(>2 \mathrm{~mm} /<2 \mathrm{~mm})$ has $65 \%$ of gravel (max. value $72 \%$, min. value $51 \%$ ) and $35 \%$ of sand and mud (max. value $49 \%$, min. value $28 \%$ ). The diamicton is intercalated by orange to yellowish sand layers at $138.9 \mathrm{~m}, 133.6 \mathrm{~m}, 121.6 \mathrm{~m}$, $121.2 \mathrm{~m}, 120.9 \mathrm{~m}$, and $117.1 \mathrm{~m}$ (Fig. 5). These sandy layers are several $\mathrm{cm}$ in thickness and partly show inclined bedding. The bottom contacts of the sand layers are fuzzy, while the top contacts are sharp. The presence of the sand layers is used to distinguish this unit from the overlying strata.

Unit $2(117.0-24.25 \mathrm{~m})$ is dominated by massive, matrixsupported sandy gravel and contains individual gravel layers. Gravel-sized clasts (5 to $10 \mathrm{~cm}$ in diameter) in the diamicton are mostly subangular to subround and occur throughout the unit (Fig. 5). In colour and size the clasts resemble those of unit 1 . They tend to be more rounded when they occur in ice-rich gravel layers (i.e. layers with excess ice). Gravel layers are commonly 5 to $20 \mathrm{~cm}$ thick and occur throughout the unit (i.e. at $116.8 \mathrm{~m}, 112.4 \mathrm{~m}, 106.5 \mathrm{~m}$, $104.4 \mathrm{~m}, 100.1 \mathrm{~m}, 99.5 \mathrm{~m}, 97.9 \mathrm{~m}, 95.0 \mathrm{~m}, 94.1 \mathrm{~m}, 93.2 \mathrm{~m}$, $80.2 \mathrm{~m}, 69.0 \mathrm{~m}, 62.8 \mathrm{~m}, 59.55 \mathrm{~m}, 57.5 \mathrm{~m}, 52.3 \mathrm{~m}, 42.4 \mathrm{~m}$, 


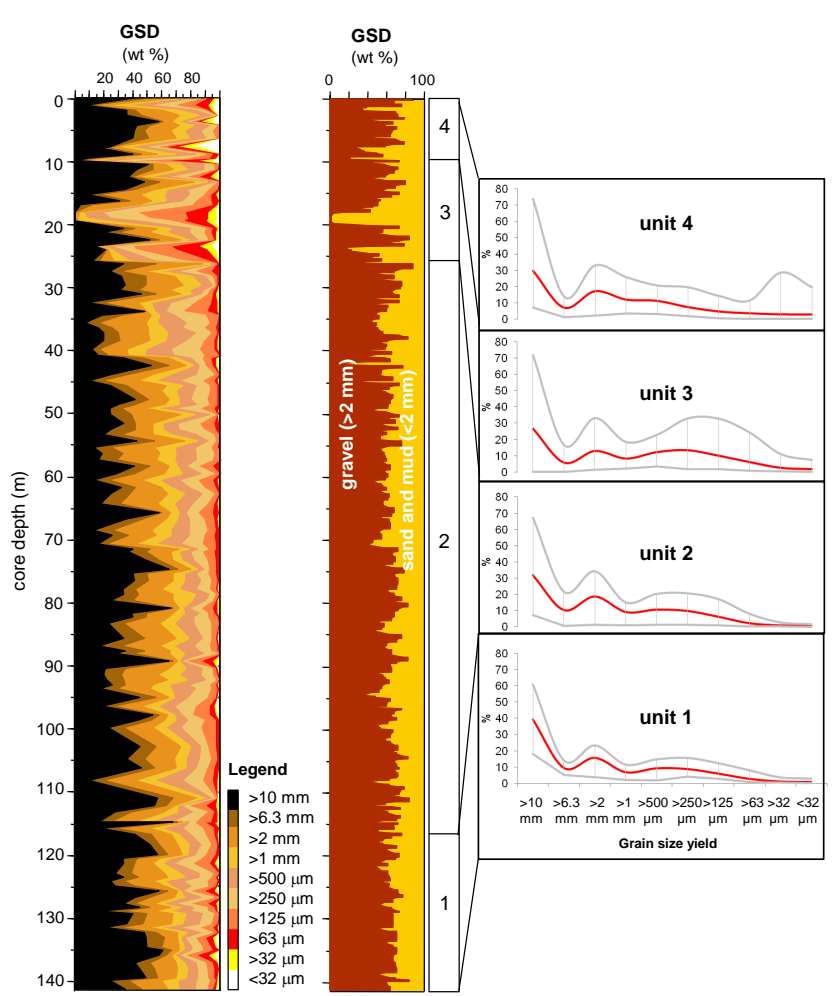

Fig. 6. Grain size distribution (GSD) and gravel/sand+mud boundary for core 5011-3, and modal grain size composition in units 1 to 4 (red line $=$ mean, upper grey line $=$ maximum, lower grey line and minimum).

$41.0 \mathrm{~m}, 37.95 \mathrm{~m}, 27.65 \mathrm{~m}, 26.45 \mathrm{~m})$. The lack of distinct sediment changes and a visually fairly constant diamictic grain size composition are most characteristic of this unit. The modal composition in this unit is similar to unit 1 ; it peaks in the medium gravel portion $(>10 \mathrm{~mm})$ followed by a distinct mode in the fine pebble fraction and a minor portion in the coarse to medium sand fraction $(>500 \mu \mathrm{m} ;>250 \mu \mathrm{m})$ (Fig. 6). The gravel-to-sand boundary slightly differs in this unit from unit 1; it has $61 \%$ of gravel (max. value $88 \%$, min. value $28 \%$ ) and $39 \%$ of sand and mud (max. value $72 \%$, min. value $12 \%$ ). At $49.65 \mathrm{~m}$ core depth, organic remains have been found and identified as pieces of lithified wood.

Unit 3 (24.25-8.5 m) has matrix-supported sandy gravel to gravelly sand that is interrupted by sand beds (Fig. 5). The multi-coloured gravel-sized clasts in the diamicton are mostly subangular to subround and occur throughout the unit, as in unit 2 . The pale red to orange coloured sand beds occur at 24.25-23.55 m, 23.2-23.05 m, 19.45-19.3 m, 18.9$18.8 \mathrm{~m}, 18.4-18.0 \mathrm{~m}, 16.5-16.2 \mathrm{~m}, 10.1-10.0 \mathrm{~m}$, and $9.6-$ $9.1 \mathrm{~m}$; they have $\mathrm{cm}$ to $\mathrm{dm}$ thick sand layers (e.g. at $16.5-$ $16.2 \mathrm{~m}$ ) and are partly fining upwards (i.e. at $18.4-18.0 \mathrm{~m}$ ). The diamicton parts generally resemble the underlying units. The modal composition in this unit peaks in the medium gravel portion $(>10 \mathrm{~mm})$, followed by a distinct mode in the fine pebble fraction (Fig. 6). The peak in the coarse to medium sand fraction $(>500 \mu \mathrm{m} ;>250 \mu \mathrm{m})$ is more pronounced than in the underlying units 1 and 2 . The high sand portion in this unit is also pronounced in the gravel-to-sand boundary; the gravel portion amounts to $45 \%$ (max. value $84 \%$, min. value $2 \%$ ) and the sand and mud portion to $55 \%$ (max. value $98 \%$, min. value $16 \%$ ). As with unit 1 , the presence of the sand layers is used to distinguish unit 3 from the underlying and overlying strata.

Unit $4(8.5-0.0 \mathrm{~m})$ consists of a matrix-supported sandy gravel with varying ice contents (Fig. 5). Occasionally samples are supersaturated with moisture, e.g. at $1.8 \mathrm{~m}$ or at $1.5 \mathrm{~m}$. In colour, size and shape the gravel-sized clasts are similar to the underlying strata. Unlike the underlying parts, this unit has various layers composed of componentsupported diamicton, especially towards the top of the core, e.g. at $3.05-2.85 \mathrm{~m}$ and at $0.6-0.0 \mathrm{~m}$. The modal composition in this unit peaks in the medium gravel portion $(>10 \mathrm{~mm})$, followed by a distinct mode in the fine pebble fraction. The peak in the coarse to medium sand fraction ( $>500 \mu \mathrm{m} ;>250 \mu \mathrm{m}$ ) is less pronounced than in the underlying units 1, 2, and 3 (Fig. 6). In contrast, there is a noticeable portion of fine sand and coarse silt in this unit. The gravelto-sand boundary shows a gravel portion of $54 \%$ (max. value $88 \%$, min. value $19 \%$ ) and a sand and mud portion of $46 \%$ (max. value $81 \%$, min. value $12 \%$ ). Sub-millimetre sized plant remains are scattered in the uppermost two metres and are intermixed with the sandy matrix.

\subsection{Mineralogy and organic matter content}

In terms of mineralogy the core material is traced using the quartz, feldspar and pyroxene components (Fig. 4). The amount and the average individual size of feldspar macro crystals vary visibly in the volcanic clasts and along the core. When expressed in a kalifeldspar-to-plagioclase ratio (K-Fsp/Plg), it ranges between 0.5 and 1.5. This is regarded a range that indicates minor change of source rock geology when compared with other sediment records where these values can be up to 4 to 8 in different lithostratigraphic units (e.g. Vogt, 2009). Exceptionally, there are higher values up to 3.5 at $121.8 \mathrm{~m}$ and $101.2 \mathrm{~m}$ depth. Quartz-tofeldspar ratios (Qrz/Fsp) as well as pyroxene occurrence (Pyx/TPA; TPA $=$ total peak area) do not change markedly along the core; within a range of 0.1 and 0.4 the quartzto-feldspar ratios change and the pyroxene signal with respect to the overall mineralogical signal ranges between 0.1 and 0.2. For comparison, elsewhere those ratios can reach up to 4 and express lithostratigraphic units (e.g. Vogt, 2009), which is not obvious in core 5011-3. Geological mapping has identified rhyolithic volcanics that appear as tuffs and ignimbrites in the western area (Belyi, 1998). Therefore, the sample debris is classed as a monomictic breccia. The fluctuating kalifeldspar-to-plagioclase ratio points to minor variability of the upland drainage basin geology. 


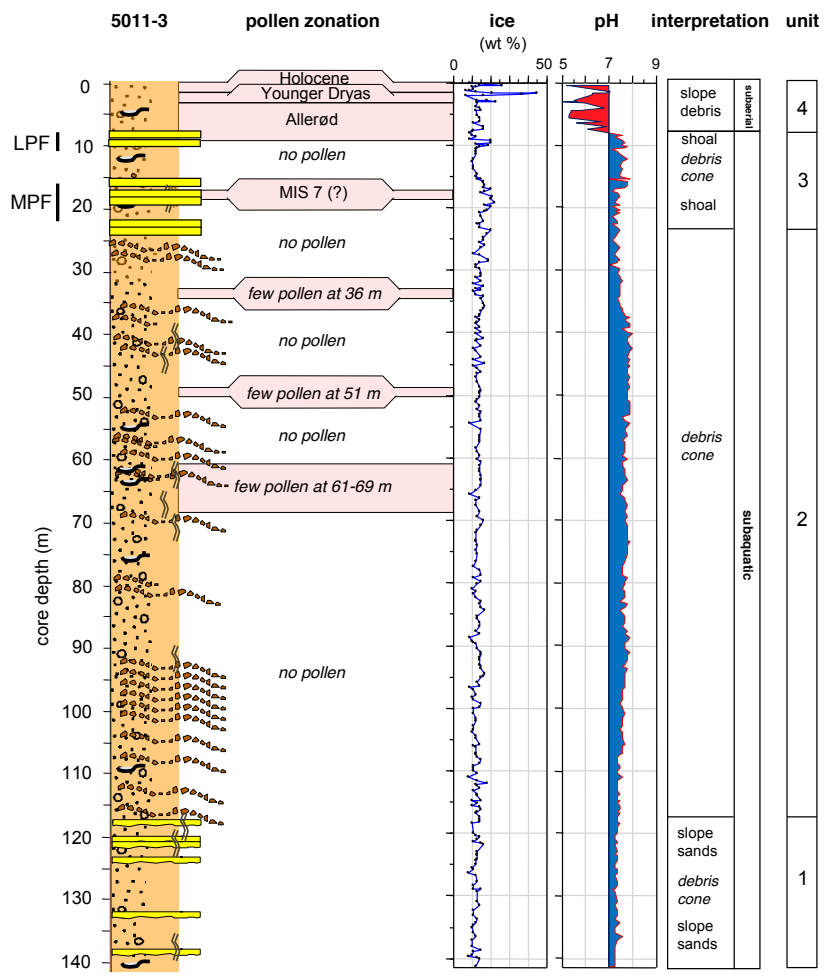

Fig. 7. The lithological log of core 5011-3 with pollen zones (partly shown as stratigraphic zones; MIS $=$ marine isotope stage), ground ice properties (ice content and $\mathrm{pH}$ ), and depositional interpretation. $\mathrm{LPF}=$ Late Pleistocene flooding event; $\mathrm{MPF}=$ Middle Pleistocene flooding event.

The core contains organic matter only to a minimal amount (Fig. 4). In the uppermost two metres some, TOC values reach more than $5 \mathrm{wt} \%$. Below two metres and down to $20 \mathrm{~m}$ core depth, TOC is not detectable. Between $20 \mathrm{~m}$ core depth and the core bottom, only individual measurements have been conducted on samples that had a pollen load. However, also those samples had TOC values below the detection limit.

\subsection{Ground ice characteristics}

The ground ice in the core is mostly formed as ice cement, i.e. the intrasedimental ice fills the pore space that is available within the sediment layers. In sediment units 1,2 , and 3 the pore ice ranges between 10 and $20 \mathrm{wt} \%$ (per cent gross weight). In some unit 4 samples, pore ice exceeds $20 \mathrm{wt} \%$ and it can reach up to $45 \mathrm{wt} \%$ within the upper three metres of the core (Fig. 7). Exceptionally, the ground ice forms crusts around gravel-sized clasts or forms ice inclusions where sediment packing is looser, e.g. at $140.0 \mathrm{~m}$, $108.4 \mathrm{~m}, 74.2 \mathrm{~m}, 63.55 \mathrm{~m}, 61.75 \mathrm{~m}, 54.5 \mathrm{~m}, 18.0 \mathrm{~m}, 11.0 \mathrm{~m}$, and $4.1 \mathrm{~m}$ (see also Fig. 4). Ice crusts have grown at the bottom side of the clasts, especially in unit 2 deposits, e.g. at $128.8 \mathrm{~m}, 123.4 \mathrm{~m}, 94.8 \mathrm{~m}, 88.7 \mathrm{~m}, 75.3 \mathrm{~m}, 62.2 \mathrm{~m}, 54.1 \mathrm{~m}$,
$38.0 \mathrm{~m}, 14.1 \mathrm{~m}$, and $2.0 \mathrm{~m}$. Some sediment samples show ice-filled cracks, suggesting that ruptured sediment has been healed by ice veins at a postsedimentary stage when the slope was not fully frozen, e.g. at $138.6 \mathrm{~m}, 121.8 \mathrm{~m}, 120.4 \mathrm{~m}$, $118.0 \mathrm{~m}, 93.4 \mathrm{~m}, 70.4 \mathrm{~m}, 70.05 \mathrm{~m}, 68.4 \mathrm{~m}, 66.8 \mathrm{~m}, 64.4 \mathrm{~m}$ (see Fig. 4), $46.3 \mathrm{~m}, 44.5 \mathrm{~m}, 41.3 \mathrm{~m}, 40.9 \mathrm{~m}$, and $19.5 \mathrm{~m}$. The cracks have various orientations and lengths; they can be vertical to horizontal, and they are commonly $1-2 \mathrm{~cm}$ thick and up to $10 \mathrm{~cm}$ long.

The $\mathrm{pH}$ of the thawed ground ice can be subdivided into two main zones: (i) between 141.5-8.5 m core depth (units 1 to 3 ), the $\mathrm{pH}$ values range between 7 and 8 ; and (ii) between $8.5-0.0 \mathrm{~m}$ (unit 4 ), the $\mathrm{pH}$ values are slightly acidic, ranging between 5 and 7 (Fig. 7). The boundary between the two parts is sharp and is used to support the differentiation between units 3 and 4 .

The acidic $\mathrm{pH}$ range of the upper core part $(8.5-0.0 \mathrm{~m})$ resembles $\mathrm{pH}$ conditions of the modern lake water or nearsurface permafrost. The $\mathrm{pH}$ measurements indicate that El'gygytgyn Crater Lake is circumneutral to weakly acidic (Cremer et al., 2005). Similarly, ground ice in frozen soil and ice wedges exhibits weakly acidic $\mathrm{pH}$ values between 6 and 7 (Schwamborn et al., 2006). Based on EC measurements in 2000 and 2003 it was concluded that ion-depleted meltwaters mainly feed the lake; the specific conductivity in El'gygytgyn Crater Lake was very low. This was also confirmed by selected conductivity measurements in snow samples and inlet streams in 2003, all indicating specific conductivities below $25 \mu \mathrm{S} \mathrm{cm}^{-1}$ (Cremer and Wagner, 2003). The acidic pore ice $\mathrm{pH}$ of unit 4 thus resembles modern surface water conditions, whereas the higher $\mathrm{pH}$ of units 1,2 , and 3 differs from the subaerial signature.

\subsection{Pollen content}

A comprehensive documentation of the pollen stratigraphy can be found in the accompanying paper by Andreev et al. (2012). The correlation of pollen zones is based on a comparison with two fairly well-dated five-metre cores extracted from slopes in the area (P1 and P2, Fig. 1). In the following a summary is given and the correlated pollen zones are displayed in Fig. 8.

The pollen record in core 5011-3 is discontinuous (Fig. 7); unit 1 does not contain any pollen, spores or other palynomorphs except from a few pollen grains found between $121.8 \mathrm{~m}$ and $123.5 \mathrm{~m}$ depth. In the core units 2,3 , and 4 , the pollen and spores are also very rare. Relatively rich pollen assemblages are found between 65.9-61.4 $\mathrm{m}$ depth in unit 2, where the sample at 65.9-65.7 $\mathrm{m}$ depth contains numerous pollen of Artemisia, Poaceae, and Asteraceae. However, the overlying sediments (65.3-63.55 $\mathrm{m}$ depth) contain rather abundant amounts of pine pollen with some larch, fir, spruce, and hemlock pollen. Samples at 51.8-51.6 m, 51.3$51.1 \mathrm{~m}$, and $35.9-35.8 \mathrm{~m}$ depth contain pollen of herbs and shrubs. 

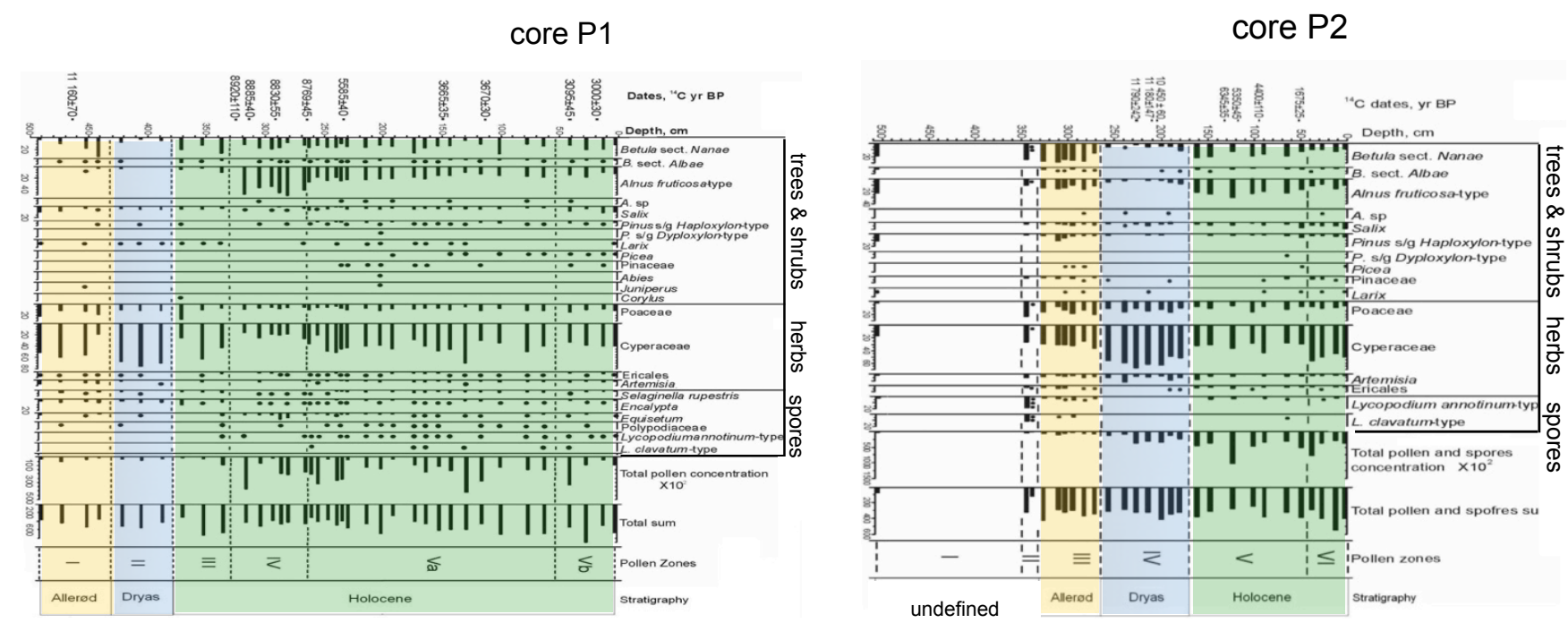

core $5011-3$

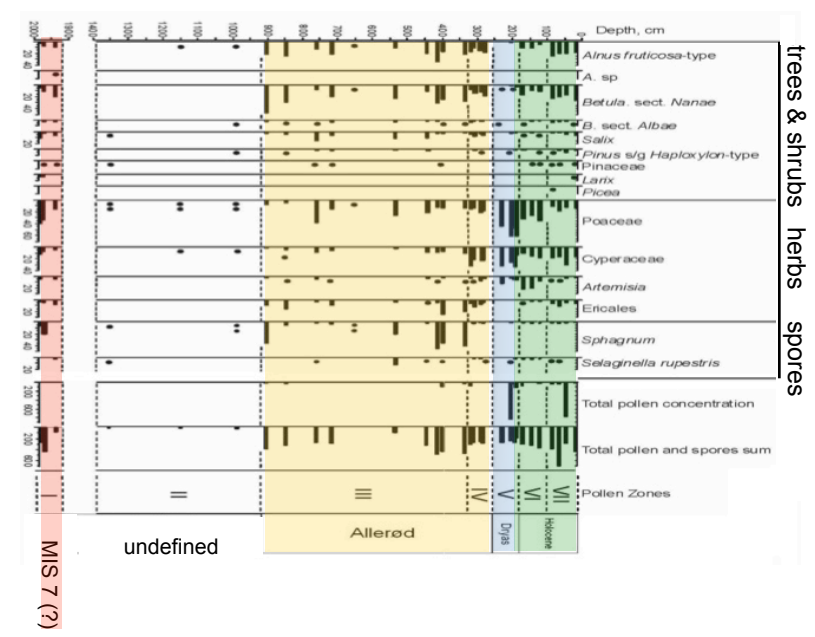

Fig. 8. Correlation of the pollen stratigraphy in permafrost core 5011-3 (bottom) with ${ }^{14}$ C-dated cores P1 and P2 (from: Andreev et al., 2012).

In unit 3, sediments at $19.8 \mathrm{~m}$ and $19.3 \mathrm{~m}$ depth pollen of alder and birch and Sphagnum spores occur (Fig. 8). The pollen assemblages are dominated by Alnus fruticosa, Betula sect. Nanae and Poaceae. However, pollen of Salix, Cyperaceae, Ericales, Caryophyllaceae and spores of Sphagnum, Lycopodium and Huperzia are also important components of the spectra. Based on a comparison with other core results from the area, this pollen content argues for an interglacial assemblage, possibly MIS 7, even though this interpretation remains debatable.

In unit 4 between $9.5-2.5 \mathrm{~m}$, the core has a relatively high pollen concentration, including tree pollen such as alder (Alnus fruticosa) and birch (Betula sect. Nanae) next to Salix, Cyperaceae, Poaceae, Ericales and spores of Sphagnum (Fig. 8). When compared with other core results from the area, this pollen zone is linked to Allerød.
The $2.5-1.8 \mathrm{~m}$ core section lacks those tree and shrub pollen and instead is dominated mostly by Cyperaceae and Poaceae pollen. Most likely this association represents the Younger Dryas in the area. Between $1.8-1.0 \mathrm{~m}$ alder ( $\mathrm{Al}$ $n u s)$ and birch (Betula), pollen occur again along with high numbers of Artemisia, while from $1.0-0.0 \mathrm{~m}$ the pollen association is dominated by Betula sect. Nanae, Alnus fruticosa, Cyperaceae, Poaceae, and Ericales. This pollen content is associated with the Holocene based on comparison with other well-dated core records (Fig. 8).

\section{Discussion}

The EAFD has features that are common to both alluvial fans and deltaic depositional systems; the proximal area in front of the mountain ridge framing the crater can be described as 


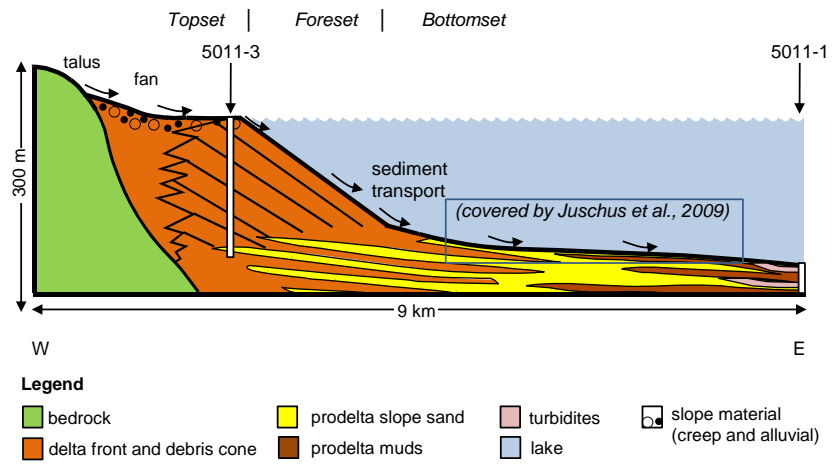

Fig. 9. A proposed simplified view of the El'gygytgyn western margin that combines known lithologies of cores 5011-3 and 5011-1 and studies of mass movements on the lake floor by Juschus et al. (2009). Note that the bottom of core 5011-3 encounters sediments from the deeper slope area. Turbidites known from core 5011-1 are expected in the deeper basin as a continuation of the prograding sediment transport from the west.

a fan setting, whereas the distal part forms a deltaic environment. Characteristic of deltas is a deposit built by a terrestrial feeder system, typically alluvial, into or against a body of standing water (Nemec, 1990), in this case a lake. The result is a localized, often irregular progradation of the shoreline controlled directly by the terrestrial feeder system, with possible modification by basinal processes, such as the action of waves or lake level change. The site of maximum deposition may shift through time and sediment change in the stratigraphic column may occur through autogenic forcing. Most of the coarse-grained (i.e. sandy gravel) material that makes up core 5011-3 and the slope at the shoreline as depicted from the bathymetry corresponds to facies types and depositional zones that are typical for a Gilbert-type fan delta (Postma, 1995). In Fig. 7, a downcore interpretation of the depositional environments is given, and in Fig. 9, a resulting scheme is proposed that includes the delta progradation and the basin bathymetry. The gravity-induced sediment transport tends to remove sediment basinward from the delta system into subaqueous fan and basin floor environments (Galloway, 1975). In El'gygytgyn Crater Lake such mass movements on the lake floor have been identified based on seismic and core data (Juschus et al., 2009).

\subsection{Interpretation of the depositional environment}

According to the proposed scheme (Fig. 9), the core sediment units 1 to 4 are interpreted as follows. Unit 1 corresponds to material from a deeper position that forms the bottomset beds on the delta front slope. The stratified layers of sand deposited as sediment masses have cascaded down into deeper waters, where hydraulic sorting has left coarser grains (i.e. gravel) further upslope. The diamicton layers are associated with mass movements, whereas the inclined bedding of the medium-to-coarse sand layers argues for settling events in the water column, i.e. from high-energy stream flows in a deep slope position.

Unit 2 has a coarse-grained portion with gravel that is typical of the debris cone of a Gilbert-type fan delta and its slope. Mass wasting on the slope is incited by oversteepening of the depositional slope, and a mixture of slope and channel transport is suggested to control sediment accumulation. Individual lobes where these deposits have formed on the slope may have migrated through time. The high-energy conditions on the slope have prevented clay and pollen from sedimenting out. The ratio of bed load (sand and gravel) to suspended load (clay and silt) is a chief but complex factor for determining the energetic environment (Galloway, 1975). However, suspended load is also particularly susceptible to loss from the system via waves and stream drift or currents, and is virtually absent in the cored material of 5011-3. Instead, it is described from cores from the centre of the lake basin (Juschus et al., 2007; Melles et al., 2012). Thus, the finer portions of the sediment load are transported further downslope where they build up graded layers in the deeper basin, which define the basin floor record of the mass wasting events. Lake sediment core 5011-1 consists of up to $30 \%$ of such turbiditic layers and documents the basin floor end of the slope cascade (Kukkonen et al., 2012). According to the pollen contents at 65.9-65.7 $\mathrm{m}$ core depth, a rather treeless, cold and dry environment is indicated for the relevant time. In contrast, the pollen assemblages at $65.3-63.55 \mathrm{~m}$ can be associated with an interglacial (marine isotope stage (MIS) 11?) based on the similar relative occurrence of these pollen in the corresponding unit in lake core 5011-1 (Melles et al., 2012). Pollen findings at 51.8-51.6 $\mathrm{m}, 51.3-51.1 \mathrm{~m}$, and $35.9-35.8 \mathrm{~m}$ depth are again linked to cold-climate Pleistocene conditions.

In unit 3 , the sedimentary environment is similar with the exception of the sand beds at the bottom and the top of this unit. The ice content is low (10-20 wt \%) in units 1 , 2 , and 3, which is thought to support the interpretation of subaqueous deposition where grains are packed densely in the course of prograding sediment transport. The sandy layers at $19.8 \mathrm{~m}$ and $19.3 \mathrm{~m}$ depth were probably formed during an interglacial based on the correlation of the pollen assemblages with lacustrine records (Lozkhin and Anderson, 2006; Lozkhin et al., 2007; Matrosova, 2009). They are not dated, but the comparison with pollen records shows that the spectra are very similar to those from the E14 zone of the infrared-optical stimulated luminescence (IR-OSL)dated Lz1024 lacustrine core (Juschus et al., 2007; Matrosova, 2009). Based on that pollen zone comparison, we suggest a MIS 7 age for the sand layers between $20.0-19.0 \mathrm{~m}$ depth. However, an older age for the revealed interglacial interval cannot be completely excluded. The sandy layers between $9.5-9.1 \mathrm{~m}$ are linked to the Allerød as another warmclimate period of sand deposition based on the pollen stratigraphy. The variability and complexity of this unit is associated with a depositional setting in the near shore environment where lake-level changes have caused an imprint on 
the sediment deposition. Sediment cores extracted from the modern near shore zone at $10 \mathrm{~m}$ water depth show sandy layers alternating with pebble-rich layers in the upper $2 \mathrm{~m}$ of core (Juschus et al., 2011). The sandy lake bed from that water depth appears similar to the sandy layers forming the bottom and the top of unit 3 in core 5011-3, thus supporting the interpretation of a subaqueous deposition of these sand layers. As introduced earlier, in the same study a lake level lowstand at $-10 \mathrm{~m}$ below the present has been reconstructed for the LGM (Juschus et al., 2011). Consequently, the sandy gravel below the Allerød sandy layers were temporarily exposed to subaerial conditions. This includes reworking of sediment in the surf zone or by ice shoving and subaerial slope processes. Periodic snowmelt impulses may have carried migrating lobes of gravel and sand into the near shore zone in- and outside the shoreline. In terms of the relatively massive nature of the sandy gravel, we suggest a highenergy depositional environment in the lake margin that is associated with mass wasting and reworking of deposits on the subaqueous slope. Indirect evidence for fairly constant mass wasting through time comes from sediment cores from the centre of the lake and their turbidity record. A total 28 turbidites have been counted in the $16.7 \mathrm{~m}$ long Lz1024 core, which stretches over $300000 \mathrm{yr}$ (Juschus et al., 2009). The turbidites measure from a few centimetres to more than 40 centimetres in thickness and occur in cold-climate periods as well as in warm-climate periods, with no obvious correlation to one of the two climate modes. This suggests that mass wasting events occur independently of climate history and might be more related to episodic oversteepening of the subaqueous slopes (Juschus et al., 2009) and random gravityinduced sliding in the course of sheet flooding during spring and storm events in summer.

Unit 4, which has overridden these strata, is characterized by varying pore space volume in loosely packed material. Unit 4 represents the delta top facies in a channel environment on the subaerial delta plain where topset beds are formed by stream activity. This environment combines migrating channel activity and slope processes on the tundra surface. It is thought to mirror the present surface conditions with creek fill accumulation and slope processes during the Holocene according to the pollen load stratigraphy, because unit 4 is the only core portion with a seemingly timecontinuous pollen record including Allerød, Younger Dryas, and Holocene pollen associations (Fig. 8). The plant detritus in the uppermost two metres of core points to reworked material that is associated with slope and soil mixing processes in the modern and ancient active layer. The layers between 9.5-2.5 $\mathrm{m}$ are associated with the Allerød given the similar pollen spectra in other deposits from the area, which have been dated accordingly (Schwamborn et al., 2006, 2008; Andreev et al., 2012). The pollen load at $2.5-1.8 \mathrm{~m}$ core depth points to a cooling climate in the area that is attributed to the Younger Dryas based on a comparison with aforementioned pollen records. The topmost section above $1.8 \mathrm{~m}$ represents

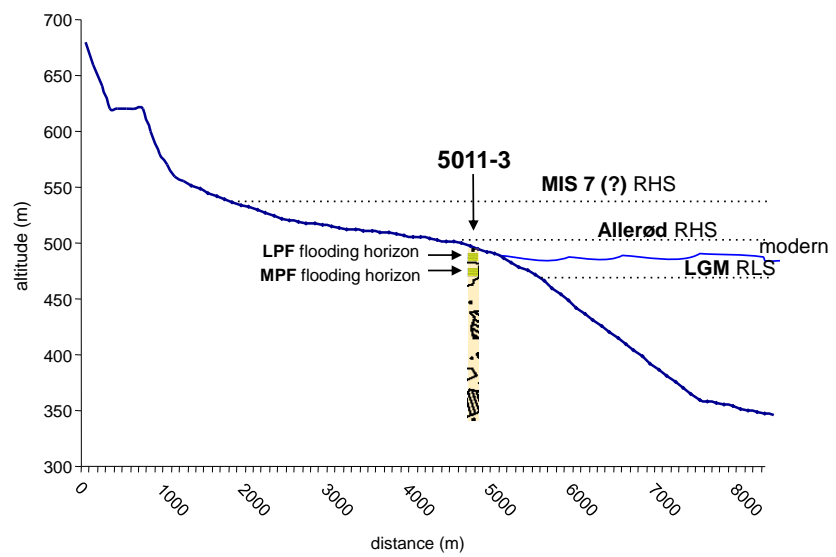

Fig. 10. Core position with respect to Quaternary lake level changes and interpreted flooding horizons. Altitudinal positions of the relative highstands (RHS) are based on Glushkova and Smirnov (2007). The position of the relative lowstand (RLS) is based on Juschus et al. (2011). LPF and MPF refer to interpreted lithological events (see also Fig. 7).

the Holocene towards modern time conditions. Five accelerator mass spectrometry (AMS) ${ }^{14} \mathrm{C}$ datings of plant remains between $1.0-0.0 \mathrm{~m}$ show all modern ages (Andreev et al., 2012), pointing to reworking soil dynamics in the active layer.

Observably, the pollen record is reliable only in the upper $\sim 9.5 \mathrm{~m}$ and this includes about $7 \mathrm{~m}$ of deposits with an Allerød pollen association. To a lesser extent the pollen information from the sand beds between $20.0-19.0 \mathrm{~m}$ depth is useful since it links this sedimentary event to a warm-climate period. From the El'gygytgyn Lake record analysis, the MIS 7 period has been interpreted to be the warmest epoch during the last four climatic cycles based on the pollen stratigraphy (Lozkhin et al., 2007; Matrosova, 2009).

\subsection{Permafrost formation in the EAFD and lake level history}

Our definition of a part of this fan as a delta necessitates a word about the near-shore environment. The El'gygytgyn shoreline is built up by a series of pebble bars that are annually modified by ice-rafting and wave activity during the open water season. According to Orton and Reading (1993) and in concert with the Gilbert-type character, the sandy to gravelly composition, as recovered in most of the cores, points to an alluvial fan or braidplain setting and a high topographic gradient. Tectonics, climate, and water level changes are among the controls on fan delta environments and facies (Bull, 1977), and autostratigraphy in a delta setting can create a variety of formations in the stratigraphic sequence without external forcing (Muto et al., 2007; Paola et al., 2009). Susceptibility of source rocks to erosion and denudation of uplands can be different and may produce weathering 
debris and accumulation bodies of varying amounts. Past glacial erosion and material dumping can play a role, although this has been outruled at least for the Late Pleistocene by Glushkova (2001). Seismic surveys of the lake basin do not show evidence of glacial excavation of the basin either (Niessen et al., 2007). Still, we cannot totally rule out the listed external and internal forcings on the EAFD formation, but based on the available studies there are no data that could fill this knowledge gap.

However, there is coincidence between the timing of reconstructed past lake level changes based on present-day geomorphology (Glushkova and Smirnov, 2007; Juschus et al., 2011) and the prominent sandy horizons in core 50113. The water level in El'gygytgyn Crater Lake is known to have fluctuated in the past. A Middle Pleistocene-aged shoreline at $540 \mathrm{~m}$ a.s.l. and a Late Pleistocene aged shoreline at $500 \mathrm{~m}$ a.s.l. have been inferred from terrace deposits at the relevant positions in the lake's catchment (Glushkova and Smirnov, 2007; Fig. 1). A water level higher than today occurred during the Allerød when the lake level was $5 \mathrm{~m}$ higher than it is at present (Schwamborn et al., 2008). The series of pebble bars that are especially visible along the northern shoreline illustrate the subsequent lake level receding after the Allerød position. A lake level $10 \mathrm{~m}$ lower than at present has been dated to MIS 2 age after sampling a corresponding subaqueous terrace at that water depth (Juschus et al., 2011). It was concluded that lower water levels are linked to cold-climate periods, whereas the $40 \mathrm{~m}, 10 \mathrm{~m}$, and $5 \mathrm{~m}$ terraces that mark higher lake levels are associated with warmclimate periods (Juschus et al., 2011). Given that the surface of the coring site is $8 \mathrm{~m}$ higher than the modern lake level and the uppermost Allerød beach line is $5 \mathrm{~m}$ above the modern lake level, we must expect to hit Allerød material at $3 \mathrm{~m}$ depth in the core. In fact, the pollen record provides an Allerød-time pollen composition below $2.5 \mathrm{~m}$ core depth. In total the sediment layers bearing an Allerød pollen record are as thick as $7 \mathrm{~m}$; this includes the sandy beds between 9.6 and $9.1 \mathrm{~m}$ core depth. We interpret these sandy layers as the flooding horizons of the Late Pleistocene, namely the Allerød lake level transgression (LPF in Fig. 7). Hereafter, when the lake level receded, subaerial shoreline pebble bars were deposited on top of the sand layers. Based on the pollen assemblage, the ancient Allerød pebble bar deposits measure 6 $\mathrm{m}$ thick, similar to the thickness of the ancient pebble bars exposed at the northern shoreline.

The sand beds at ca. 20.0-19.0 m core depth are attributed to the warm stage MIS 7, according to the interpretation of the pollen record in the deposits. In analogy to the Allerød flooding event, a similar lake level situation is postulated for that time that flooded the coring site at that time. This lake level MIS 7 event (Middle Pleistocene flooding $=$ MPF in Fig. 7) in our core is matched by a corresponding event that has been identified in a lake sediment record; a lake core (Lz1028) has been sampled $8.2 \mathrm{~m}$ below the modern water depth from a subaqueous cliff-like bench in the southern part of the lake and so-called "deep water sediments" at 2.38$2.48 \mathrm{~m}$ core depth have been dated to $185 \pm 22 \mathrm{ka}$ using IRSL (Infrared Stimulated Optical Luminescence) (Juschus et al., 2011). Based on their similar absolute topographic position and the available age indications, these two strata from the two cores should be synchronous events. For the corresponding time Juschus et al. (2011) reconstructed a high lake level of unknown absolute height. For the time period posterior to the MIS 7 event, Juschus et al. (2011) claim a lake level drop even lower than $-10 \mathrm{~m}$ below present, since they found an erosional contact in their lake sediment record. Remnants of a $10 \mathrm{~m}$ terrace that can be found on the south banks of the lake indicate another lake level higher than present, which - based on the pollen contents of the lower and the upper units of this $10 \mathrm{~m}$ terrace - is believed to be of MIS 3 to MIS 2 age (Glushkova and Smirnov, 2007). The lake sediment study by Juschus et al. (2011) confirms a water level higher than present at about $40 \mathrm{ka}$ before present. However, in our core 5011-3 there are no corresponding strata that have recorded this high lake level event. Rather, the deposits overlying the MIS 7 strata are interpreted to result from mass wasting and possibly reworking of local material. It is only during the Allerød that another lake level higher than modern is recorded again in core 5011-3, as already outlined in the previous section. Figure 10 illustrates the known Quaternary lake level changes with respect to the coring position of 5011-3. The coring site has been exposed at least since the post-Allerød lake level receding. The shoreline retreat, which left behind a series of shoreline bars that are visible on the north banks, enabled the freezing front that surrounds the lake to migrate basinwards and subaqueous slope sediments have been incorporated into permafrost. Presumably in synchrony with the freezing process, some sediment packages slumped or subsided as indicated by the ice-filled cracks, which are most often seen in unit 2 deposits. The freezing process seems to alter the water chemistry in the pore space as expressed by the $\mathrm{pH}$; the formerly subaqueous environment can now be identified by downcore basic $\mathrm{pH}$ values in units 1,2 , and 3 . Within the subaerially deposited shoreline, pebble bars formed on top of the Allerød flooding horizon; the $\mathrm{pH}$ values change to more acidic values, pointing to modern surface water and soil water conditions in the pore space.

In the material of unit 4, frequent seasonal freeze-thaw cycling in the soil and associated physical weathering has happened during the accumulation on the subaerial slope. In fact, in this unit we find an increased portion of fine grained material (fine sand and silt; Fig. 6), which is a typical result from frost weathering action in the area (Schwamborn et al., 2012). In contrast, units 1 to 3 , which have been formed under subaquatic conditions, have escaped intense soil weathering and the post-depositional freezing only happened twice after the two known episodic flooding events and the subsequent shore line retreat that allowed the freezing front to migrate across the study site. Still, we cannot exclude the possible destruction of primary sedimentary structure and 
sediment grains due to post-depositional freezing in the material of units 1 to 3 .

\subsection{EAFD formation and regional tectonics}

The imprint of climatic episodes on EAFD formation is hindered by the lack of an age model for core 5011-3. Still, climate change may certainly have affected the increase or decrease in sediment yields, and thus may have resulted in accelerated fan delta deposition (Bull, 1977). Deciphering the climate change as recorded in the lake sediment record is the main goal of various accompanying papers (e.g. Chapligin et al., 2012; Melles et al., 2012). Notwithstanding, understanding the forcing of the Quaternary climate cycles on the EAFD formation might be improved in the future when an age model for core 5011-3 becomes available.

\section{Summary}

The 5011-3 El'gygytgyn permafrost well provided the unique opportunity to study the sedimentary composition of the western crater margin. We interpret the $141.5 \mathrm{~m}$ long core consisting of sandy, gravelly, and diamictic strata as belonging to a fan delta body fed by alluvial material transport and slope processes. The lower core part (units 1,2, and 3) was deposited under subaqueous conditions before lake level receding and progradational sediment transport led to subaerial deposition of Holocene-to-recent channel and slope material (unit 4).

The depositional environment is progradational and mass wasting occurs on the foreslope of the delta. This may have consequences when interpreting the numerous turbiditic layers in the 5011-1 sediment core from the centre of the lake. The studied EAFD on the western crater side is presumably a dominant source of turbidity released into the basin. The EAFD is representative of more sediment fans in the western and northern sector of El'gygytgyn Crater, where a braidplain environment semi-surrounds the lake.

The initial cause for the fan formation is seen in local to regional scale tectonics with block uplift in the Okhotsk-Chukchi mountain belt. This may also be the cause of the lake's shift from the crater centre towards the east.

Acknowledgements. Funding for this research was provided by the ICDP, the US National Science Foundation (NSF), the German Federal Ministry of Education and Research (BMBF), the Alfred Wegener Institute for Polar and Marine Research (AWI) and GeoForschungsZentrum Potsdam (GFZ), the Russian Academy of Sciences Far East Branch (RAS FEB), the Russian Foundation for Basic Research (RFBR), and the Austrian Federal Ministry of Science and Research (BMWF). A Russian mining rig (SIF-650M) was employed by Sergey Gutov and his crew from a local drilling company (Chaun Mining Corp., Pevek). The lab support by Antje Eulenburg and Ute Bastian is highly appreciated. The authors would like to thank the two reviewers J. Tunnicliffe and anonymous as their valuable and constructive remarks greatly improved the early version of the manuscript.

Edited by: P. Minyuk

\section{References}

Andreev, A. A., Morozova, E., Fedorov, G., Schirrmeister, L., Bobrov, A. A., Kienast, F., and Schwamborn, G.: Vegetation history of central Chukotka deduced from permafrost paleoenvironmental records of the El'gygytgyn Impact Crater, Clim. Past, 8, 1287-1300, doi:10.5194/cp-8-1287-2012, 2012.

Beaty, C. B.: Age and estimated rate of accumulation of an alluvial fan. White Mountains, California, USA, Am. J. Sci., 268, 50-77, 1970.

Belyi, V. F.: Impactogenesis and volcanism of the Elgygytgyn depression, Petrology, 6, 86-99, 1998.

Belyi, V. F. and Raikevich, M. I.: The El'gygytgyn hollow - geology and morphology, impactites, problems of research and protection of an inanimate nature, NEISRI FEB Russian Acad. Sci., Magadan, 1994 (in Russian).

Blair, T. C. and McPherson, J. G.: Alluvial fans and their natural distinction from rivers based on morphology, hydraulic processes, sedimentary processes, and facies assemblages, J. Sediment Res., A64, 450-489, 1994.

Blott, S. J. and Pye, K.: GRADISTAT: A grain size distribution and statistics package for the analysis of unconsolidated sediments, Earth Surf. Proc. Land., 26, 1237-1248, 2001.

Bull, W. B.: The alluvial-fan environment, Prog. Phys. Geog., 1, 222-270, 1977.

Chapligin, B., Meyer, H., Swann, G. E. A., Meyer-Jacob, C., and Hubberten, H.-W.: A 250 ka oxygen isotope record from diatoms at Lake El'gygytgyn, far east Russian Arctic, Clim. Past, 8, 1621-1636, doi:10.5194/cp-8-1621-2012, 2012.

Cremer, H. and Wagner, B.: The diatom flora in the ultraoligotrophic Lake El'gygytgyn, Chukotka, Polar Biol., 26, 105114, 2003.

Cremer, H., Wagner, B., Juschus, O., and Melles, M.: A microscopical study of diatom phytoplankton in deep crater Lake El'gygytgyn, northeast Siberia, Algolog. Stud., 116, 147-169, doi:10.1127/1864-1318/2005/0116-0147, 2005.

Densmore, A. L., Allen, P. A., and Simpson, G.: Development and response of a coupled catchment fan system under changing tectonic and climatic forcing, J. Geophys. Res., 112, F01002, doi:10.1029/2006JF000474, 2007.

Folk, R. L.: The distinction between grain size and mineral composition in sedimentary-rock nomenclature, J. Geol., 62, 344-359, 1954.

Folk, R. L. and Ward, W. C.: Brazos River bar: A study in the significance of grain size parameters, J. Sediment. Petrol., 27, 3-26, 1957.

Fujita, K., Koz'min, B. M., Mackey, K. G., Riegel, S. A., McLean, M. S., and Imaev, V. S.: Seismotectonics of the Chersky Seismic Belt, eastern Sakha Republic (Yakutia) and Magadan District, Russia, Stephan Mueller Spec. Publ. Ser., 4, 117-145, 2009.

Galloway, W. E.: Process framework for describing the morphologic and stratigraphic evolution of deltaic depositional systems, in: Deltas: Models for exploration, edited by: Broussard, M. L., Houston, TX, Houston Geological Society, 87-98, 1975. 
Glushkova, O. Yu.: Geomorphological correlation of Late Pleistocene glacial complexes of Western and Eastern Beringia, Quaternary Sci. Rev., 20, 405-417, 2001.

Glushkova, O. Yu and Smirnov, V. N.: Pliocene to Holocene geomorphic evolution and paleogeography of the Elgygytgyn Lake region, NE Russia, J. Paleolimnol., 37, 37-47, 2007.

Harvey A. M.: The coupling status of alluvial fans and debris cones: a review and synthesis, Earth Surf. Proc. Land., 37, 64-76, doi:10.1002/esp.2213, 2012.

Harvey, A. M., Mather, A. E., and Stokes, M.: Alluvial fans: geomorphology, sedimentology, dynamics - introduction. A review of alluvial-fan research, Geological Society, London, Special Publications, 251, 1-7, doi:10.1144/GSL.SP.2005.251.01.01, 2005.

Haug, E. W., Kraal, E. R., Sewall, J. O., Van Dijk, M., and Chong Diaz, G.: Climatic and geomorphic interactions on alluvial fans in the Atacama Desert, Chile, Geomorphology, 121, 184-196, 2010.

Juschus, O., Preusser, F., Melles, M., and Radtke, U.: Applying SAR-IRSL methodology for dating finegrained sediments from Lake El'gygytgyn, northeastern Siberia, Quat. Geochronol., 2, 187-194, 2007.

Juschus, O., Melles, M., Gebhardt, C., and Niessen, F.: Late Quaternary mass movement events in Lake El'gygytgyn, northeastern Siberia, Sedimentology, 56, 2155-2174, 2009.

Juschus, O., Pavlov, M., Schwamborn, G., Preusser, F., Fedorov, G., and Melles, M.: Late Quaternary lake-level changes of Lake El'gygytgyn, NE Siberia, Quaternary Res., 76, 441-451, 2011.

Kukkonen, M., Juschus, O., Gebhardt, C., Wennrich, V., Cook, T., Melles, M. and the El'gygytgyn Scientific Party: Mass movement deposits in the 3.6 Ma sediment record of Lake El'gygytgyn, Chukotka, NE Siberia: Classification, distribution and preliminary interpretation. Clim. Past, submitted, 2012.

Layer, P. W.: Argon-40/argon-39 age of the El'gygytgyn impact event, Chukotka, Russia, Meteor. Planet. Sci., 35, 581-599, 2000.

Lozhkin, A. V. and Anderson, P. M.: A reconstruction of the climate and vegetation of northeastern Siberia based on lake sediments, Paleontol. J., 40, 622-628, 2006.

Lozhkin, A. V., Anderson, P. M., Matrosova, T. V., and Minyuk, P. S.: The pollen record from El'gygytgyn Lake: Implications for vegetation and climate histories of northern Chukotka since the late middle Pleistocene, J. Paleolimnol., 37, 135-153, 2007.

Matrosova, T. V.: Vegetation and climate change in northern Chukotka during the last $350 \mathrm{ka}$ based on lacustrine pollen records from El'gygytgyn Lake, Vestnik FEB RAS, 2, 23-30, 2009 (in Russian).

McEwen, L., Owen, G., Matthews, J. A., and Hiemstra, J. F.: Late Holocene development of a Norwegian alpine alluvial fan affected by proximal glacier variations, episodic distal undercutting, and colluvial activity, Geomorphology, 127, 198-215, 2011.

Melles, M., Brigham-Grette, J., Minyuk, P., Koeberl, C., Andreev, A., Cook, T., Fedorov, G., Gebhardt, C., Haltia-Hovi, E., Kukkonen, M., Nowaczyk, N., Schwamborn, G., Wennrich, V. and the El'gygytgyn Scientific Party: The Lake El'gygytgyn scientific drilling project - conquering Arctic challenges through continental drilling, Scientific Drilling, 11, 2940, doi.10.2204/iodp.sd.11.03.2011, 2011.
Melles, M., Brigham-Grette, J., Minyuk, P., Nowaczyk, N., Wennrich, V., DeConto, R., Anderson, P. M., Andreev, A. A., Coletti, A., Cook, T. L., Haita-Hovi, E., Kukkonen, M., Lozkhin, A. V., Rosén, P., Tarasov, P., Vogel, H., and Wagner, B.: 2.8 Million years of Arctic climate change from Lake El'gygytgyn, NE Russia, Science, 337, 315-320, doi:10.1126/science.1222135, 2012.

Mottaghy, D., Schwamborn, G., and Rath, V.: Past climate changes and permafrost depth at the Lake El'gygytgyn site: implications from data and thermal modelling, Clim. Past Discuss., 8, 26072644, doi:10.5194/cpd-8-2607-2012, 2012.

Muto, T., Steel, R., and Swenson, J. B.: Autostratigraphy: a framework norm for genetic stratigraphy, J. Sediment. Res., 77, 2-12, 2007.

Nemec, W.: Deltas - remarks on terminology and classification, Spec. Publs., Int. Ass. Sediment, 10, 3-12, 1990.

Niessen, F., Gebhardt, C. A., Kopsch, C., and Wagner, B.: Seismic investigation of the El'gygytgyn impact crater lake (Central Chukotka, NE Siberia): Preliminary results, J. Paleolimnol., 37, 49-63, 2007.

Nolan, M. and Brigham-Grette, J.: Basic hydrology, limnology, and meteorology of modern Lake El'gygytgyn, Siberia, J. Paleolimnol., 37, 17-35, 2007.

Nowaczyk, N. R., Minyuk, P., Melles, M., Brigham-Grette, J., Glushkova, O., Nolan, M., Lozhkin, A. V., Stetsenko, T. V., Andersen, P., and Forman, S. L.: Magnetostratigraphic results from impact crater Lake El'gygytgyn, northeastern Siberia: A 300 kyr long high-resolution terrestrial paleoclimate record from the Arctic, Geophys. J. Int., 150, 109-126, 2002.

Orton, G. J. and Reading, H. G.: Variability of deltaic processes in terms of sediment supply, with particular emphasis on grain size, Sedimentology, 40, 475-512, 1993.

Paola, C., Straub, K., Mohrig, D. C., and Reinhardt, L.: The "unreasonable effectiveness" of stratigraphic and geomorphic experiments, Earth-Sci. Rev., 97, 1-43, 2009.

Petschick, R., Kuhn, G., and Gingele, F.: Clay mineral distribution in surface sediments of the South Atlantic: Sources, transport, and relation to oceanography, Mar. Geol., 130, 203-229, 1996.

Postma, G.: Sea-level-related architectural trends in coarse-grained delta complexes, Sediment. Geol., 98, 3-12, 1995.

Schwamborn, G., Meyer, H., Fedorov, G., Schirrmeister, L., and Hubberten, H.-W.: Ground ice and slope sediments archiving Late Quaternary paleoclimate and paleoenvironment signals at the margins of Lake El'gygytgyn impact crater, NE Siberia, Quaternary Res., 66, 259-272, 2006.

Schwamborn, G., Fedorov, G., Schirrmeister, L., Meyer, H., and Hubberten, H.-W.: Periglacial sediment variations controlled by lake level rise and Late Quaternary climate at El'gygytgyn Crater Lake, Arctic Siberia, Boreas, 37, 55-65, 2008.

Seeberg-Elverfeldt, J., Schlüter, M., Feseker, T., and Kölling, M.: Rhizon sampling of pore waters near the sediment/water interface of aquatic systems, Limnol. Oceanogr.-Meth., 3, 361-371, 2005.

Stone, D. B., Layer, P. W., and Raikevich, M. I.: Age and paleomagnetism of the Okhotsk-Chukotka Volcanic Belt (OCVB) near Lake El'gygytgyn, Chukotka, Russia, Stephan Mueller Spec. Publ. Ser., 4, 243-260, 2009. 
Vogt, C.: Data report: Semiquantitative determination of detrital input to ACEX sites based on bulk sample X-ray diffraction data, in: Proceedings IODP, 302, edited by: Backman, J., Moran, K., McInroy, D. B., Mayer, L. A., and the Expedition 302 scientists, Edinburgh (Integrated Ocean Drilling Program Management International, Inc.), doi:10.2204/iodp.proc.302.203.2009, 2009.

Vogt, C., Knies, J., Spielhagen, R. F., and Stein, R.: Detailed mineralogical evidence for two nearly identical glacial/deglacial cycles and Atlantic water advection to the Arctic Ocean during the last 90,000 years, Global Planet. Change, 31, 23-44, 2001.
Wennrich, V., Francke, A., Dehnert, A., Juschus, O., Leipe, T., Vogt, C., Brigham-Grette, J., Minyuk, P. S., Melles, M., and El'gygytgyn Science Party: Modern sedimentation patterns in Lake El'gygytgyn, NE Russia, derived from surface sediment and inlet streams samples, Clim. Past Discuss., 8, 2007-2039, doi:10.5194/cpd-8-2007-2012, 2012.

Yershov, E. D.: General Geocryology. Studies in Polar Research, Cambridge Univ. Press, English Edition, 1998. 